\author{
ks. Robert Tyrata \\ Uniwersytet Papieski Jana Pawta II w Krakowie \\ Akademia Muzyczna w Krakowie \\ Międzyuczelniany Instytut Muzyki Kościelnej
}

\title{
Muzyka podczas papieskich pielgrzymek w archidiecezji krakowskiej (1979-2006)
}

Pielgrzymki papieskie w archidiecezji krakowskiej zawsze były wielkim duszpasterskich wyzwaniem, a także ważnym wydarzeniem dla wielu ludzi wierzących. W przedstawieniu tematu konieczne jest uczynienie pewnego założenia, a mianowicie, że w biorąc pod uwagę całość zebranego na ten temat materiału, niniejsze opracowanie musi dotyczyć nie tylko samych utworów (kompozycji) wykonywanych podczas liturgii, ale musi być przywołaniem osób, które tę muzykę tworzyły. Powiemy więc tutaj o komitetach muzyczny papieskich pielgrzymek, kompozytorach tworzących na zamówienie Kościoła i artystach (scholach, chórach, orkiestrach, solistach, kantorach, dyrygentach)., oczywiście nie zapominając też o wiernych uczestniczących w tej modlitwie.

\section{Wstęp}

Muzyka jako „integralna część uroczystej liturgii” (KL 112) podczas pielgrzymek papieży - Jana Pawła II i Benedykta XVI - była w sposób należyty przygotowana i przeżywana zarówno podczas uroczystych liturgii, jak i innych spotkań z papieżami. W archidiecezji krakowskiej obyło się dziewięć takich pielgrzymek. Papież Jan Paweł II przybył do archidiecezji w latach 1979 (Kraków, Kalwaria Zebrzydowska, Wadowice, Nowy Targ), 1983 (Kraków), 1987 (Kraków), 1991 (dwa razy: Kraków w czerwcu, Wadowice w sierpniu), 1997 (Kraków, Zakopane, Ludźmierz), 1999 (Kraków), 2002 (Kraków). Papież Benedykt XVI przybył do Polski jeden raz - w 2006 roku - był w Krakowie i Wadowicach.

Przeżywane 50-lecie podpisania pierwszego dokumentu soborowego Sacrosanctuum concilium staje się także dobrą okazją, by pokazać troskę o ten aspekt działalności Kościoła, jakim jest muzyka kościelna, przedstawić pokolenia ludzi odpowiedzialnych za nią w archidiecezji krakowskiej w latach 1978-2006. Dla wszystkich tych ludzi muzyka była czytelnym znakiem i szczególnym wymiarem 
modlitwy podczas papieskich spotkań z wiernymi w Krakowie i innych miejscach archidiecezji. Z całą też pewnością liturgie papieskie nie są zbyt łatwe do przygotowania, zwłaszcza gdy mamy do czynienia z różnorodnością rozumienia muzyki kościelnej przez osoby przygotowujące liturgię. Wszystko jednak ostatecznie zbiera się w jedną całość, by stać się językiem uroczystej modlitwy pod przewodem następcy św. Piotra. Wydaje się, iż w dużej mierze udało się to uzyskać we wszystkich tych papieskich pielgrzymkach $\mathrm{w}$ archidiecezji.

\section{Pielgrzymki papieża Jana Pawła II do archidiecezji krakowskiej}

Podczas pierwszej pielgrzymki ojca świętego Jana Pawła II do Polski w 1979 roku podczas liturgii na krakowskich Błoniach połączone chóry śpiewały: Mikołaja Zieleńskiego Tu es Petrus, Gaude Mater Polonia, sekwencję Jesu Christe rex superne, Wesel się, Polska Korono, Jerzego Libana Ortus de Polonia, Wacława z Szamotuł Powszednia spowiedź, tego samego kompozytora Ego sum pastor bonus, Mikołaja Zieleńskiego O gloriosa Domina i Bogurodzicę . Śpiewano ponadto mszę jednogłosową z ludem skomponowaną przez Mariana Machurę, a także pieśni: Wesel się, Polsko cata z muzyką Ireny Pfeiffer i tekstem napisanym przez Marka Skwarnickiego ${ }^{2}$, Bądźże pozdrowiona, Panie, pragnienia ludzkich serc, Ciebie Boga wystawiamy, Dzięki, o Panie, Boże, coś Polskę ${ }^{3}$ Z okazji tej pierwszej pielgrzymki i liturgii na Błoniach zebrano dziewczęta i chłopców z Krakowa, by śpiewali w scholi pod dyrekcją ks. Jacka Żurka4 . Na organach grali Marian Machura ${ }^{5}$ i Mieczysław Tuleja. Śpiew z wiernymi prowadził ks. Jacek Żurek. Papież odwiedził także katedrę wawelską i Sanktuarium Pasyjno-Maryjne w Kalwarii Zebrzydowskiej oraz Nowy Targ.

Trzeba także tutaj przywołać sytuację związaną z przygotowaniem kompozycji Beatus Vir przez Henryka Mikołaja Góreckiego. Utwór zamówiony został przez kard. Karola Wojtyłę, jego premiera zaś miała miejsce 9 czerwca 1979 roku w ko-

1 Zob. Na jubileusz św. Stanistawa (zeszyt chóralny), Kraków 1979.

2 Pieśń została napisana specjalnie na jubileusz 900-lecia śmierci św. Stanisława BM. Uczono jej w całej archidiecezji jako liturgicznego przygotowania do uroczystości.

3 Zob. I pielgrzymka Jana Pawta II do Krakowa, Archiwum Kurii Metropolitalnej w Krakowie, bez. sygn.

4 Piszący te słowa sam w tej scholi jako dziecko śpiewał.

5 Zob. Wspomnienia o pielgrzymkach papieskich doc. Mariana Machury z dnia 19 maja 2014 roku, Archiwum Archidiecezjalnej Komisji Muzyki Kościelnej, bez. sygn.; R. Tyrała, Jan Pawet II $w$ muzyce polskiej, praca magisterska napisana pod kierunkiem prof. Adama Walacińskiego, Akademia Muzyczna w Krakowie 1997. 
ściele OO. Franciszkanów. Był na niej obecny ojciec święty Jan Paweł II ${ }^{6}$. Tak fakt ten wspomina Marian Machura:

jeszcze przed wyborem kard. Karola Wojtyły na biskupa Rzymu uczestniczyłem w jego obecności w zebraniu poszerzonej komisji. Celem spotkania było przygotowanie uroczystości jubileuszowej św. Stanisława. Kiedy posiedzenie dobiegło końca, ks. Stanisław Dziwisz zwrócił się do ks. kardynała z propozycją i pytaniem, czy nie byłoby dobrze, aby dla uczczenia jubileuszu powstało oratorium. Ten uznał to za świetny pomysł i poprosił mnie, abym zajął się tą sprawą (byłem w tym czasie przewodniczącym Podkomisji do Spraw Muzyki Kościelnej). Z przejęciem przyjąłem tę propozycję. W domu, podzieliwszy się z żoną tą informacją, jednomyślnie zdecydowaliśmy, iż kompozytorem powinien być Henryk Mikołaj Górecki. Udaliśmy się do Katowic i przedstawiliśmy list ks. kardynała Góreckiemu, piastującemu wówczas urząd rektora tamtejszej Akademii Muzycznej. Z wzruszeniem przyjął propozycję i obiecał podjąć pracę nad oratorium. Czas mijał, a profesor Górecki nie potrafił zadecydować co do doboru odpowiednich tekstów. W międzyczasie świat obiegła radosna nowina: kardynał z Krakowa, Karol Wojtyła, został wybrany papieżem i wkrótce odwiedzi Kraków. Profesor Górecki przyparty terminem, zdecydował się na uniwersalny tekst dla oratorium - psalm Beatus vir. Wiadomość, iż komponuje oratorium, zaczęła się roznosić, aż Górecki został wezwany do komitetu wojewódzkiego PZPR w Katowicach, gdzie sekretarz Grudzień postawił mu ultimatum: „albo przestaniecie pisać dla papieża, albo przestaniecie być rektorem Akademii Muzycznej”. Profesor Górecki nie wahał się i natychmiast zrezygnował z posady rektora, skupiając się na dalszej pracy nad oratorium ${ }^{7}$.

Dalej też w swoim wspomnieniu tyniecki organista pisze:

Chcąc dowiedzieć się w kurii, w którym kościele odbędzie się wykonanie, udałem się do ks. kanclerza, który stanowczo stwierdził: „wybijcie sobie

6 Zob. R. Tyrała, Polska muzyka sakralna inspirowana osoba i dziatalnościa Jana Pawta II, „Polonia Sacra” VIII (XXVI) nr $15 / 59$ (2004), s. 353-376; R. Tyrała, Kulturowy i religijny kontekst twórczości kompozytorskiej Henryka Mikotaja Góreckiego (+2010). „Niebiańskie polany” jako przestanie jego kompozytorskiej twórczości, „Pro Musica Sacra”, t. 9, Kraków 2011, s. 11-17.

7 Wspomnienia o pielgrzymkach papieskich doc. Mariana Machury z dnia 19 maja 2014 roku, Archiwum Archidiecezjalnej Komisji Muzyki Kościelnej, bez. sygn. 
z głowy to oratorium, papieże nie chodzą na koncerty!”. Podzieliłem się mą troską z siostrą felicjanką, Mariolą Ferdułą, sekretarką Instytutu Liturgicznego. Ta udzieliła mi informacji, iż akurat w celu ustalenia szczegółowego planu wizyty papieskiej w Krakowie przebywa ks. Stanisław Dziwisz i u ss. Felicjanek codziennie odprawia mszę świętą. Przyjechałem więc na jedną z tych mszy, po której przy herbacie w krótkich słowach przedstawiłem problem oratorium. Następnego dnia w kurii powiedziano mi, że ojciec święty po spotkaniu z biskupami świata przejdzie wraz z nimi na drugą stronę ulicy do kościoła Franciszkanów, gdzie będzie uczestniczył w wykonaniu Beatus vir. Tak też się stało. Połączone orkiestry i chóry Filharmonii Krakowskiej oraz Polskiego Radia poprowadził sam kompozytor, natomiast solową partię wykonał baryton Jerzy Mechliński. Kościół wypełniony był po brzegi, a artyści otrzymali gromkie brawa. Jeszcze przy trwającym aplauzie dyrygent podszedł do papieża, który to, jak relacjonował później sam Górecki, miał zwrócić się do ks. Dziwisza: „Stasiu, daj” i wręczyć kompozytorowi specjalnie przygotowany na tę okazję medal pamiątkowy ${ }^{8}$.

Podczas drugiej pielgrzymki w 1983 roku ojciec święty Jan Paweł II dokonał na krakowskich Błoniach aktu beatyfikacji Rafała Kalinowskiego i Alberta Chmielowskiego9. W Krakowie w skład komisji muzycznej pielgrzymki weszli reprezentanci poszczególnych ośrodków muzycznych Krakowa: Jacek Berwaldt (Filharmonia Krakowska), Marian Machura (opactwo tynieckie), Stanisław Gałoński (Capella Cracoviensis), Stanisław Krawczyński (chór Filharmonii Krakowskiej), Tadeusz Dobrzański (Filharmonia Krakowska), Juliusz Łuciuk, Irena Pfeiffer, Bronisława Wietrzny (chór Polskiego Radia), Jerzy Jamiński (chór „Con Amore”), Barbara Karpała (Schola Cantrum Cracoviensis), Adam Korzeniowski chór męski Uniwersytetu Jagiellońskiego), Jan Rybarski (Chór Mariański), Zbigniew Ciuraba (chór Akademii Ekonomicznej „Dominanta”), Andrzej Białko (organy), Władysław Radwan (organy), Mieczysław Tuleja (organy). Pracami komisji kierował ks. Józef Szczotkowski, przewodniczący Komisji ds. Muzyki Kościelnej Archidiecezji Krakowskiej ${ }^{10}$. Zachował się w Archiwum Kurii Metropo-

8 Wspomnienia o pielgrzymkach papieskich doc. Mariana Machury z dnia 19 maja 2014 roku, Archiwum Archidiecezjalnej Komisji Muzyki Kościelnej, bez. sygn.

9 Zob. Modlitewnik pielgrzyma. Z Janem Pawtem II w archidiecezji krakowskiej, 4-10 czerwca 1997, red. S. Koperek, Kraków 1997, s. 10.

${ }^{10}$ II Pielgrzymka Jana Pawta II do Krakowa w 1983 roku, Archiwum Kurii Metropolitalnej w Krakowie, bez. sygn. 
litalnej protokół z posiedzenia komisji w dniu 6 maja 1983 roku. Dowiadujemy się z niego, że

omówiono udział chórów w głównym nabożeństwie na Błoniach w dniu 22 czerwca. W skład głównego chóru śpiewającego podczas mszy św. papieskiej wchodzą: chór Polskiego Radia, filharmonii, wawelski katedralny, cecyliański, mariański i „Organum”. Ten sam zespół śpiewał na Błoniach podczas pierwszej wizyty ojca Świętego ${ }^{11}$.

$\mathrm{Na}$ kolejnym posiedzeniu komisji w dniu 10 czerwca 1983 roku ustalono, że na rozpoczęcie liturgii chór wykona Tu es Petrus Mikołaja Zieleńskiego, a lud zaśpiewa Kiedy ranne wstaja zorze, na przygotowanie darów ofiarnych chór wykona Ojcze z niebios Stanisława Moniuszki, na komunię Ps. 137 Do Boga Stanisława Moniuszki, Powstańcie, powstańcie i Chwalcie Pana Ps. 112 tego samego kompozytora na zakończenie liturgii, zaś wraz z ludem Bogurodzicę i Magnificat ${ }^{22}$. $\mathrm{Na}$ organach podczas liturgii grali Marian Machura i Mieczysław Tuleja, a śpiew z wiernymi prowadził ks. Jacek Żurek. Podczas tej liturgii poza wymienionymi już zespołami śpiewał także chór z katedry tarnowskiej Pueri Cantores Tarnovienses pod dyr. ks. Andrzeja Zająca ${ }^{13}$.

W czasie trwania pielgrzymki w wawelskiej katedrze miało miejsce zamknięcie Synodu Prowincji Krakowskiej i tam podczas spotkania z ojcem świętym wykonano Tu es Petrus oraz Ortus de Polonia i Gaude Mater Polonia Jerzego Libana z Legnicy, Totus tuus Henryka Mikołaja Górckiego, a także $Z$ bandera krzyża na masztach Michała Woźnego. Podczas tej uroczystości śpiewały chóry: męski chór katedralny pod dyr. Michała Woźnego i akademicki chór „Organum” pod dyr. Bogusława Grzybka ${ }^{14}$.

Trzecia pielgrzymka Jana Pawła II w Krakowie miała miejsce w 1987 roku. 10 czerwca ojciec święty odprawił na krakowskich Błoniach mszę i w tym samym

${ }^{11}$ Protokót z posiedzenia komisji muzycznej pielgrzymki papieża w 1983 w Krakowie, II Pielgrzymka Jana Pawta II do Krakowa w 1983 roku, Archiwum Kurii Metropolitalnej w Krakowie, bez. sygn.

12 II Pielgrzymka Jana Pawta II do Krakowa w 1983 roku, Archiwum Kurii Metropolitalnej w Krakowie, bez. sygn.

${ }^{13}$ Wspomnienie ks. prof. J. Żurka, Archiwum Archidiecezjalnej Komisji Muzyki Kościelnej, bez. sygn.; zob. zdjęcie w publikacji z okazji kanonizacji Jana Pawła II, podpis: „27 IV 2014 Watykan, Msza św. kanonizacyjna papieży Jana XXIII i Jana Pawła II”, red. M. Koch-Butryn, s. 40 .

${ }^{14}$ II Pielgrzymka Jana Pawła II do Krakowa w 1983 roku, Archiwum Kurii Metropolitalnej w Krakowie, bez. sygn. 
dniu dokonał podniesienia relikwii Jadwigi Króla Polski do wawelskiej katedry. Potwierdził tym aktem istniejący obecny od wieków kult pani wawelskiej i ogłosił, że winna ona nosić tytuł błogosławionej.

$\mathrm{Na}$ Błoniach śpiewały połączone chóry miasta Krakowa i schola OO. Bernardynów. Na rozpoczęcie liturgii śpiewano z wiernymi Bogurodzicę, następnie Kyrie z Litanii Ostrobramskiej Stanisława Moniuszki, Gloria Mariana Machury, na przygotowanie darów ofiarnych O gloriosa Domina Mikołaja Zieleńskiego, Santus Juliusza Łuciuka i Agnus Dei z Litanii Ostrobramskiej Stanisława Moniuszki. Podczas komunii śpiewano Bądźże pozdrowiona (z ludem), Agnus Dei Grzegorza Gerwazego Gorczyckiego, Ktaniam się Tobie (z ludem), Panis Angelicus Cezara Francka, Cóż Ci, Jezu, damy (z ludem), Ave verum Wolfganga Amadeusza Mozarta, następnie Ireny Pfeiffer Uwielbienie Eucharystii, na dziękczynienie Uwielbiaj, duszo moja (z ludem), zaś na zakończenie liturgii chóry śpiewały Litanię Ostrobramska Stanisława Moniuszki ${ }^{15}$. W przygotowanym na tę liturgię zeszycie nutowym zamieszczono i wykonano także Tu es Petrus Mikołaja Zieleńskiego, Do kraju tego Józefa Świdra, Spraw niech ptaczę Karola Szymanowskiego, Ta chwila catego życia Edwarda Burego ${ }^{16}$. Na organach grali Marian Machura i Mieczysław Tuleja, śpiew z wiernymi prowadził ks. Jacek Żurek.

We wspomnieniach tynieckiego organisty - Mariana Machury - odnajdziemy ciekawe odniesienie do tego wydarzenia, a także przywołanie postaci wielce zasłużonej dla muzyki kościelnej w Krakowie, a mianowicie Ireny Pffeifer ${ }^{17}$. Pisze on:

pragnę przypomnieć barwną i zasłużoną dla Kościoła postać pani Ireny Pffeifer, która przez długie lata prowadziła krakowskie chóry męskie i żeńskie w klasztorach. Jest autorką akatystu polskiego do słów Marka Skwarnickiego oraz pieśni Wesel się Polsko cata do tekstu tego samego artysty. Po wojnie Irena Pffeifer ukończyła PWSM w Krakowie. Przez długie lata prowadziła chór i orkiestrę w Państwowym Liceum Muzycznym. Podczas papieskiej pielgrzymki powierzono jej kierowanie męskimi

15 Zob. III Pielgrzymka Jana Pawta II do Krakowa w 1983 roku, Archiwum Kurii Metropolitalnej w Krakowie, bez. sygn.; Na spotkanie z Janem Pawtem II. Btonia Krakowskie 10 czerwca 1987, zeszyt nutowy, Kraków 1987.

${ }^{16}$ Na spotkanie z Janem Pawtem II. Btonia Krakowskie 10 czerwca 1987, zeszyt nutowy, Kraków 1987.

${ }_{17}$ Zob. L. Biziak, Irena Pfeiffer - muzyk i pedagog, praca licencjacka napisana pod kierunkiem ks. dr Roberta Tyrały, Papieska Akademia Teologiczna w Krakowie, 2002; L. Biziak, Miejsce Ireny Pfeiffer $w$ historii muzyki kościelnej i jej wktad w świetle soborowej odnowy muzyki liturgicznej, praca magisterska napisana pod kierunkiem ks. dr Roberta Tyrały, Papieska Akademia Teologiczna w Krakowie, Kraków 2004. 
chórami na krakowskich Błoniach, prowadzenie śpiewu Gaude Mater Polonia oraz także dyrygowanie chórem na Wawelu. Pani Irena martwiła się bardzo, czy zdąży z Błoni przedostać się na Wawel, gdzie miała witać Jana Pawła II. Wątpliwościami podzieliła się z członkiem ochrony papieskiej, który zaproponował jej przeprowadzenie do jednego z autobusów czekających przy Cracovii na papieskich gości. Pamiętam, iż staliśmy z moją żoną w oczekiwaniu na przejazd Jana Pawła II przy Alejach Trzech Wieszczów, kiedy to w pewnym momencie zobaczyliśmy jadący autobus, a w nim siedzącą osamotnioną pasażerkę - panią Irenę. Mówiła nam potem, iż była przekonana, że wraz z nią autobusem byli przewożeni biskupi i kardynałowie. Następnego dnia podczas głównej mszy świętej w trakcie ofiarowania składano przed papieżem dary, wtedy też pani Irena wręczyła album swych kompozycji. Ja również miałem swój powód do wzruszenia, bowiem ks. prałat Małysiak na tę uroczystość przygotował oprawiony w białą skórę śpiewnik Ciebie Boże chwalimy, który wręczyłem Ojcu Świętemu ${ }^{18}$.

10 czerwca 1987 roku ojciec święty Jan Paweł II w odprawił w wawelskiej katedrze mszę świętą z podniesieniem relikwii bł. Jadwigi Królowej. Na powitanie papieża chór katedralny śpiewał Ecce sacerdos magnus Józefa Surzyńskiego, następnie wszyscy zebrani odśpiewali Bogurodzicę, chór Filharmonii Krakowskiej - kompozycję Ireny Pfeiffer Uwielbienie Eucharystii oraz Ego sum pastor bonus Wacława z Szamotuł. Podczas liturgii mszy śpiewano na rozpoczęcie Cicha, skromna, zamyślona z tekstem Marka Skwarnickiego i muzyką Mariana Machury, następnie In Te Domine, speravi Wacława z Szamotuł (części stałe napisane przez Mariana Machurę). Na przygotowanie darów ofiarnych odśpiewano Sub tuum praesidium Bartłomieja Pękiela, na komunię zaś Ach mój niebieski Panie Wacława z Szamotuł, $U$ drzwi Twoich stoje panie (z wiernymi), Magnificat Mikołaja Zieleńskiego, na zakończenie liturgii zaś Weź w swa opiekę (z wiernymi), a chór filharmoniczny wykonał Viderunt omnes fines terrae Mikołaja Zieleńskiego, chór katedralny z kolei - Pieśń o Królowej Jadwidze Michała Woźnego ${ }^{19}$.

Kolejna pielgrzymka (a właściwie dwie pielgrzymki) ojca świętego Jana Pawła II miała miejsce w czerwcu 1991 roku w wielu miastach Polski, a w sierpniu tego samego roku w Krakowie i Wadowicach. W Krakowie podczas mszy na Rynku

18 Wspomnienia o pielgrzymkach papieskich doc. Mariana Machury z dnia 19 maja 2014 roku, Archiwum Archidiecezjalnej Komisji Muzyki Kościelnej, bez. sygn.

${ }_{19}$ Msza święta Jana Pawta II z podniesieniem relikwii btogostawionej Jadwigi Królowej, katedra na Wawelu 10 czerwca 1987 roku, Kraków 1987. 
Głównym papież beatyfikował Aniele Salawę ${ }^{20}$. W Wadowicach papież dokonał dedykacji kościoła św. Piotra. Komisji muzycznej pielgrzymki przewodniczył ks. Jacek Żurek. W skład komisji weszli: Marian Machura, Mieczysław Tuleja, Stanisław Gałoński, Jacek Mentel i Bogusław Grzybek.

Podczas mszy beatyfikacyjnej Anieli Salawy 13 sierpnia 1991 roku na krakowskim rynku śpiewały chór i orkiestra Capella Cracoviensis pod dyr. Stanisława Gałońskiego, chór Filharmonii Krakowskiej pod dyr. Jacka Mentla oraz Akademicki Chór „Organum”. Na powitanie papieża śpiewano Tu es Petrus, następnie wierni podjęli śpiew Bogurodzicy oraz Ciebie na wieki. Podczas liturgii śpiewano części stałe (Kyrie, Gloria, Sanctus i Agnus Dei) z Mszy koronacyjnej Wolfganga Amadeusza Mozarta. Podczas ogłoszenia Anieli Salawy błogosławioną śpiewano pieśń Cóż Ci, Jezu, damy. Na przygotowanie darów ofiarnych śpiewano pieśń (z wiernymi) Panie w ofierze, a następnie Zdrowaś Maryjo. Podczas komunii wierni rozpoczęli śpiew $U d r z w i$ Twoich, następnie chór z orkiestrą wykonał Ave verum Wolfganga Amadeusza Mozarta, kolejno z wiernymi śpiewano pieśni: Twoja cześś chwata, Witam Cię witam, Ktaniam się Tobie, Jezusa ukrytego. Jako dziękczynienie wszyscy zebrani zaśpiewali Uwielbiaj, duszo moja. Na zakończenie liturgii wierni śpiewali Boże coś Polskę oraz My chcemy Boga $^{21}$. Na organach grał Marian Machura, śpiew z wiernymi prowadził ks. Jacek Żurek.

W Wadowicach papież dokonał dedykacji kościoła św. Piotra. Podczas liturgii śpiewały połączone chóry. Śpiew z wiernymi podczas liturgii oraz animację muzyczną przed i po mszy prowadziły połączone schole młodzieżowe z Wadowic, Andrychowa i innych okolicznych parafii. Scholę przygotowywał i prowadził podczas uroczystości autor tego opracowania ${ }^{22}$.

13 stycznia 1997 roku ks. kard. Franciszek Macharski powołał komitet organizacyjny pielgrzymki papieskiej, w którego skład jako odpowiedzialny za muzykę wszedł piszący te słowa. W skład komisji muzycznej pielgrzymki powołani zostali Wiesław Delimat, Witold Zalewski, ks. Marian Błaszczyk, Ewa Sterczyńska, Mieczysław Tuleja, Jerzy Kurcz, Adam Korzeniowski ${ }^{23}$. Papież odwiedził na Podhalu Zakopane (parafię Najświętszej Rodziny na Krupówkach, sanktuarium

${ }^{20}$ Zob. Modlitewnik pielgrzyma. Z Janem Pawtem II w archidiecezji krakowskiej, 4-10 czerwca 1997, dz. cyt., s. 10.

${ }^{21}$ Zob. Pielgrzymka Jana Pawta II do Krakowa w 1991 roku, Archiwum Kurii Metropolitalnej w Krakowie, bez. sygn.

${ }^{22}$ Niestety nie zachował się szczegółowy scenariusz uroczystości.

${ }^{23}$ Zob. Sktad komisji muzycznej pielgrzymki papieża Jana Pawta II do archidiecezji krakowskiej w 1997 roku, Archiwum Archidiecezjalnej Komisji Muzyki Kościelnej, bez. sygn. 
NMP Fatimskiej na Krzeptówkach i odprawił mszę pod Wielką Krokwia). Odwiedził także sanktuarium NMP Królowej Podhala w Ludźmierzu.

W 1997 roku papież Jan Paweł II odwiedził Zakopane, gdzie 6 czerwca 1997 roku podczas mszy pod Wielką Krokwią w dniu dokonał aktu beatyfikacji m.in. Bernardyny Jabłońskiej ${ }^{24}$. Za muzykę odpowiadały kapele góralskie i schola dzieci góralskich pod dyr. Ewy Sterczyńskiej i ks. Mariana Błaszczyka złożona z przeszło 500 muzyków pod kierownictwem Stanisława Michałczaka. Zespół powstał specjalnie na tę uroczystość, podobnie jak pieśń Syćka Se Wom zycom, której uczono przed przyjazdem papieża na całym Podhalu. Ponadto śpiewały chóry „Watra” z Raby Wyżnej pod dyr. Marii Możdżeń-Wójcik, „Rabiańskie Dzieci” z Raby Wyżnej pod kierunkiem tej samej dyrygentki, męski chór „Wierchy” z Zakopanego pod dyr. Władysława Kruszewskiego, „Echo Gorczańskie” z parafii NSPJ w Nowym Targu pod dyr. Piotra Augustyna, „Gorce” z Nowego Targu pod dyr. Jana Szostka, parafialny chór św. Teresy z Rabki pod dyr. ks. Romana Sapety, parafialny chór św. Magdaleny z Rabki pod dyr. Stanisława Waisa, „Adoremus” z Rdzawki pod dyr. Agnieszki Zborek, chłopięcy chór Matki Bożej Bolesnej z Limanowej pod dyr. Haliny Dyczek. Grała także Orkiestra Dęta Straży Granicznej pod dyr. kpt. Stanisława Strączka ${ }^{25}$. Organistami podczas uroczystości byli Piotr Augustyn z parafii NSPJ w Nowym Targu i Andrzej Guziak, organista z parafii Serca NMP z Zakopanego na Krzeptówkach. Wszystkie śpiewane przez chóry kompozycje znalazły się w wydanym zeszycie nutowym ${ }^{26}$. Na powitanie papieża śpiewano ks. Tu es Petrus Wacława Gieburowskiego oraz Mitys Boze kochany ze słowami do starej nuty góralskiej Franciszka Bachledy Księdzulorza w opracowaniu Stanisława Michałczaka. Liturgia rozpoczęła się śpiewem Gaude Mater Polonia, następnie podczas aktu beatyfikacji śpiewano inwokację do słów s. Akwiny Filipowicz $\mathrm{z}$ melodią Ireny Pfeiffer Btogostawiona siostro Bernardyno oraz Btogostawiona Mario Pasterko. Na przygotowanie darów ofiarnych śpiewano chóralną pieśń Serce Jezusa z nami w opr. Józefa Łasia SJ oraz Oremus pro Pontifice nostro P. Volpi. Kolejno także wykonano kompozycję Wierzę Józefa Świdra, Panis Angelicus Cesara Francka, hymn kongresu eucharystycznego z wiernymi do słów ks. Marka

${ }^{24}$ Zob. Modlitewnik pielgrzyma. Z Janem Pawtem II w archidiecezji krakowskiej, 4-10 czerwca 1997, dz. cyt., s. 50-52, 55-60.

25 Zob. Modlitewnik pielgrzyma. Z Janem Pawtem II w archidiecezji krakowskiej, 4-10 czerwca 1997, dz. cyt, s. 110.

${ }^{26}$ Zob. Komisja Muzyczna Pielgrzymki, Msza święta pontyfikalna o Najświętszym Sercu Pana Jezusa sprawowana przez Ojca Świętego Jana Pawta II, w czasie której dokona beatyfikacji siostry Bernardyny Jabtońskiej i siostry Marii Kartowskiej, Zakopane 6 czerwca 1997 roku, Kraków 1997. 
Drzewieckiego z muzyką Stefana Stuligrosza Przyszedteś, Panie. Na dziękczynienie Boże, moje serce jest gotowe z muzyką Jana Kosko w opr. Władysława Radwana. Na zakończenie zaś Btogostaw, Boże, papieża w opr. Władysława Radwana ${ }^{27}$. Śpiew $\mathrm{z}$ wiernymi prowadził piszący te słowa.

W dniu 7 czerwca 1997 roku w Sanktuarium NMP w Ludźmierzu papież odmówił z wiernymi różaniec ${ }^{28}$. Podczas tej modlitwy śpiewały chóry „Watra” z Raby Wyżnej pod dyr. Marii Możdżeń-Wójcik, „Rabiańskie Dzieci” z raby Wyżnej pod kierunkiem tej samej dyrygentki, chór męski Wierchy z Zakopanego pod dyr. Władysława Kruszewskiego, „Echo Gorczańskie” z parafii NSPJ w Nowym Targu pod dyr. Piotra Augustyna, „Gorce” z Nowego Targu pod dyr. Jana Szostka, chór parafialny św. Teresy z Rabki pod dyr. ks. Romana Sapety, chór parafialny św. Magdaleny z Rabki pod dyr. Stanisława Waisa. Grała także Orkiestra Dęta Straży Granicznej pod dyr. kpt. Stanisława Strączka ${ }^{29}$. Na organach grał Piotr Augustyn.

W dniu 8 czerwca 1997 roku papież kanonizował na krakowskich Błoniach Jadwigę Królową ${ }^{30}$. Przed liturgią kanonizacji seminarzyści Krakowa odśpiewali napisaną przez Mariana Machurę Jutrznię o bł. Jadwidze ${ }^{31}$. Podczas uroczystej liturgii śpiewały chóry: akademicki „Organum” pod dyr. Bogusława Grzybka, Chór Mariański z parafii NMP z Lourdes pod dyr. Jana Rybarskiego, Wydziału Wychowania Muzycznego Akademii Muzycznej w Krakowie pod dyr. Jerzego Kurcza, Wyższego Seminarium Duchownego Archidiecezji Krakowskiej pod dyr. piszącego te słowa, Wyższego Seminarium Towarzystwa Salezjańskiego pod dyr. Adama Korzeniowskiego, schola Ruchu Światło-Życie pod dyr. Elżbiety Chlebda, chór Papieskiej Akademii Teologicznej „Psalomodia” pod dyr. Włodzimierza Siedlika, Schola Cantorum Cracoviensis pod dyr. Barbary Karpały, Canticum Novum pod dyr. Elżbiety Ptak, Akademii Ekonomicznej „Dominanta” pod dyr. Zbigniewa Ciuraby ${ }^{32}$. Wszystkimi chórami dyrygowali: Jerzy Kurcz i Adam Korzeniowski, organistami zaś byli Mieczysław Tuleja z kościoła św. Stanisława Kost-

${ }_{27}$ Zob. Komisja Muzyczna Pielgrzymki, Msza święta pontyfikalna, dz. cyt.

${ }^{28}$ Zob. Modlitewnik pielgrzyma. Z Janem Pawtem II w archidiecezji krakowskiej, 4-10 czerwca 1997, dz. cyt., s. 61-63.

29 Zob. Modlitewnik pielgrzyma. Z Janem Pawtem II w archidiecezji krakowskiej, 4-10 czerwca 1997, dz. cyt., s. 110.

30 Zob. Modlitewnik pielgrzyma. Z Janem Pawtem II w archidiecezji krakowskiej, 4-10 czerwca 1997, dz. cyt., s. 64-72.

31 Zob. Modlitewnik pielgrzyma. Z Janem Pawtem II w archidiecezji krakowskiej, 4-10 czerwca 1997, dz. cyt., s. 85-91.

32 Zob. Modlitewnik pielgrzyma. Z Janem Pawtem II w archidiecezji krakowskiej, 4-10 czerwca 1997, dz. cyt., s. 110. 
ki w Krakowie-Dębnikach oraz Witold Zalewski - organista z wawelskiej katedry. Śpiew z wiernymi prowadził piszący te słowa.

Specjalnie na uroczystość kanonizacji powstała i została wykonana podczas liturgii kompozycja Juliusza Łuciuka Niech będzie Bóg uwielbiony ku czci św. Jadwigi Królowej. Wszystkie śpiewane przez chóry kompozycje znalazły się w wydanym zeszycie nutowym ${ }^{33}$. Na powitanie papieża śpiewano Tu es Petrus ks. Wacława Gieburowskiego, antyfonę ks. Jacka Żurka Najwyższemu Panu chwata. Liturgię rozpoczęto od Ego sum Pastor bonus Wacława z Szamotuł. Kolejno śpiewano: Parce Domine Feliksa Nowowiejskiego, inwokację do św. Jadwigi napisaną przez Irenę Pfaiffer Świętością zdobna, Alleluja ks. Grzegorza Gerwazego Gorczyckiego. Następnie chóry śpiewały także Oremus pro Pontifice nostro Juliusza Łuciuka, pieśń wspólną z wiernymi Jadwigo, Polski Królowo G. i A. Krzanowskich i Boże w dobroci ks. Jana Mańskiego. Na dziękczynienie zaśpiewano Hymn uwielbienia dedykowany Janowi Pawłowi II napisany specjalnie na tę uroczystość przez Juliusza Łuciuka. W zeszycie nutowym znalazły się także dwie pieśni do wykonania w przyszłości - Cicha, skromna, zamyślona Mariana Machury ze słowami Jacka Skwarnickiego oraz Hymn ku czci Królowej Jadwigi ks. Władysława Wargowskiego ${ }^{34}$.

9 czerwca 1997 roku w krypcie Leonarda w wawelskiej katedrze papież odprawił poranną mszę, a klerycy Wyższego Seminarium Duchowego Archidiecezji Krakowskiej pod dyrekcją piszącego te słowa śpiewali chorał gregoriański. Wchodzącego do katedry papieża witał męski chór katedralny pod dyr. Romana Mackiewicza.

Dekretem z dania 7 grudnia 1998 roku kardynał Franciszek Macharski powotał komitet organizacyjny pielgrzymki ojca świętego do archidiecezji krakowskiej, w którym sprawy muzyki powierzono piszącemu te słowa. Komisja muzyczna pielgrzymki składała się zaś z następujących członków: Jerzy Kurcz, Jacek Mentel, Włodzimierz Siedlik, Stanisław Krawczyński, Wiesław Delimat, Witold Zalewski, Mieczysław Tuleja, Małgorzata Gawor, Adam Kocyk, Piotr Pałka, Marek Seyfied ${ }^{35}$. Papież Jan Paweł II przybył do archidiecezji krakowskiej w 1999 roku.

Niestety 15 czerwca na krakowskich Błoniach papież nie przewodniczył liturgii, był bowiem chory. W jego imieniu mszę celebrował kard. Angelo Sodano,

33 Zob. Komisja Muzyczna Pielgrzymki, Kanonizacja Btogostawionej Jadwigi Królowej. Btonia Krakowskie, 8 czerwca 1997 roku, Kraków 1997.

${ }^{34}$ Zob. Komisja Muzyczna Pielgrzymki, Kanonizacja Btogostawionej Jadwigi Królowej. Btonia Krakowskie, 8 czerwca 1997 roku, dz. cyt., s. 54-55.

35 Zob. Sktad komisji muzycznej pielgrzymki papieża Jana Pawta II do archidiecezji krakowskiej w 1999 roku, Archiwum Kurii Metropolitalnej w Krakowie, bez. sygn. 
sekretarz stanu Stolicy Apostolskiej. Była to liturgia z okazji 1000-lecia diecezji krakowskiej. W specjalnie przygotowanym nutowym zeszycie umieszczone zostały wszystkie śpiewy chórów ${ }^{36}$. Podczas liturgii na rozpoczęcie połączone chóry śpiewały Gaude Mater Polonia, a Bogurodzice i Pod Twa obronę wszyscy zebrani wierni ${ }^{37}$. Na przygotowanie darów ofiarnych chóry śpiewały Viderunt omnes Mikołaja Zieleńskiego, a wszyscy wierni pieśn Kochajmy Pana oraz Jeden chleb. Na komunię wierni rozpoczęli modlitwę śpiewaną Bądźże pozdrowiona, później kolejno chór odśpiewał Magnificat, wierni Cóz Ci Jezu damy i znów chór Ach mój niebieski Panie Wacława z Szamotuł. Jako dziękczynienie wszyscy odśpiewali Ciebie Boga wystawiamy, a na zakończenie wierni śpiewali Boże coś Polskę oraz Barkę i Abba Ojcze $e^{38}$. Organistami podczas tej liturgii byli Mieczysław Tuleja z kościoła Świętego Stanisław Kostki na Dębnikach, Wiesław Delimat z kościoła Świętego Marka i dyrektor Archidiecezjalnej Szkoły Organistowskiej oraz Witold Zalewski, organista z wawelskiej katedry. Śpiew z wiernymi prowadził piszący te słowa. Podczas liturgii grała też orkiestra dęta Huty im. T. Sendzimira pod dyr. Marka Zeifieda $^{39}$. Śpiewane były także utwory przygotowane przez scholę akademicką pod dyr. Piotra Pałki, Adama Kocyka i Małgorzaty Gawor. Śpiewano: Witamy Cię, Prosimy Cię, Zostań wśród nas, Chwata Panu i cześć, Alleluja, 148 psalm, Będe śpiewat na cześć Pana, Matko scynśliwych powrotów, Panie dokąd pójdziemy, Niechaj zstapi Duch Twój ${ }^{40}$.

17 czerwca 1999 roku przy ołtarzu św. Stanisława w wawelskiej katedrze ojciec święty odprawił liturgię Eucharystii. Podczas liturgii śpiewał męski chór katedralny pod dyrekcją piszącego te słowa, na organach grał Witold Zalewski. Jako przygotowanie do liturgii zaśpiewano Jutrznię ku czci św. brata Alberta. Na powitanie papieża chór śpiewał Tu es Petrus Michaela Hallera. Na rozpoczęcie mszy śpiewano Gaude Mater Polonia (chór), następnie wszyscy zebrani zaśpiewali pieśń Pod Twa obronę. Na przygotowanie darów ofiarnych chór odśpiewał Oremus pro Ponfitice nostro Michała Woźnego, wszyscy wierni zaśpiewali zaś Jeden chleb; na komunię chór odśpiewał $O$, święta uczto Bolesława Wallek-Walewskiego, wierni - Bądźże

${ }^{36}$ Zob. Komisja Muzyczna Pielgrzymki, Msza święta sprawowana przez Ojca Świętego Jana Pawta II w Milenium Diecezji Krakowskiej. Btonia Krakowskie, 15 czerwca 1999 roku, Kraków 1999.

37 Zob. Tysiac lat diecezji krakowskiej. Eucharystia z Janem Pawtem II. Btonia Krakowskie, 15 czerwca 1999, red. S. Koperek, Kraków 1999, s. 17-18.

${ }^{38}$ Zob. Tysiac lat diecezji krakowskiej. Eucharystia z Janem Pawtem II. Btonia Krakowskie, dz. cyt., s. 33-48.

39 Zob. Pielgrzymka Jana Pawta II w Krakowie w 1999 roku, Archiwum Kurii Metropolitalnej w Krakowie, bez. sygn.

40 Zebrane śpiewy zostawały także wykorzystywane w późniejszych spotkaniach. 
pozdrowiona. Na dziękczynienie cały kościół zaśpiewał Uwielbiaj duszo moja Pana mego, zaś na zakończenie liturgii zabrzmiała Kantata ku czci św. Królowej Jadwigi napisana przez Michała Woźnego, którą zaśpiewał chór katedralny ${ }^{41}$.

19 marca 2002 roku kardynał Franciszek Macharski powołał komitet organizacyjny pielgrzymki papieża w archidiecezji krakowskiej, w skład której wszedł piszący te słowa ${ }^{42}$. Komisję muzyczną pielgrzymki tworzyli: Wiesław Delimat, Witold Zalewski, Mieczysław Tuleja, s. Katarzyna Kozubek, s. Ligia Bender, Bogusław Grzybek i Jan Rybarski ${ }^{43}$. Ojciec święty Jan Paweł II z ostatnią swoją pielgrzymką do archidiecezji krakowskiej przybył w 2002 roku. Z tej okazji 17 sierpnia 2002 roku dokonał dedykacji kościoła Bożego Miłosierdzia w Krakowie-Łagiewnikach, w którym zawierzył świat Miłosierdziu Bożemu. Następnie 18 sierpnia 2002 roku odprawił na krakowskich Błoniach uroczystą liturgię Eucharystii , a 19 sierpnia 2002 roku przy obrazie NMP w Kalwarii Zebrzydowskiej - ostatnią swoją mszę w Polsce.

Podczas uroczystej liturgii w kościele w Łagiewnikach śpiewały Chór Mariański z parafii NMP z Lourdes w Krakowie pod dyr. Jana Rybarskiego oraz międzyzakonna schola sióstr, którą na tę okazję zebrały i którą dyrygowały podczas uroczystości s. Katarzyna Kozubek ze zgromadzenia ss. starowiejskich oraz s. Ligia Bender ze zgromadzenia ss. sercanek. Dla potrzeb scholi sióstr i chóru został przygotowany zeszyt nutowy ${ }^{44}$. Na rozpoczęcie liturgii siostry śpiewały pieśń, do której muzykę napisał Leon Świerczek CM, pieśn Niech z serc poptynie w opracowaniu Wojciecha Widłaka, następnie wszyscy wierni zapiewali Pod Twą obronę. Podczas pokropienia wodą święconą ołtarza, zgromadzonych wiernych i ścian kościoła wszyscy śpiewali pieśń Przez chrztu świętego wielki dar, podczas namaszczenia ołtarza i ścian chór wykonał Locus iste Antona Brucknera, a wierni śpiewali Com przyrzekt Bogu oraz Jezu ufam Tobie. Podczas okadzania kościoła wierni śpiewali Czego chcesz od nas Panie, schola sióstr pieśń Mariana Machury Panu zaufatem, a wszyscy zebrani w kościele - Weź w swa opiekę. Podczas zapalania światła wszyscy wierni śpiewali Caty świat niech śpiewa tę pieśń. Na procesję z darami ofiarnymi schola sióstr śpiewała pieśń napisaną przez ks. Stanisława Ziemiań-

${ }^{41}$ Zob. Dziękczynienie za pielgrzymkę Ojca Świętego do Ojczyzny, Eucharystia z Janem Pawtem II przy ottarzu Ojczyzny, katedra wawelska 17 czerwca 1999, godz. 7. 30, red. S. Koperek, Kraków 1999, s. 15-31.

42 Zob. Dekret Metropolity Krakowskiego, nr 727/2002; Zob. Pielgrzymka Jana Pawta II do Krakowa w 2002 roku, Archiwum Kurii Metropolitalnej w Krakowie, bez. sygn.

${ }^{43}$ Zob. Sktad komisji muzycznej pielgrzymki papieża Jana Pawta II do Archidiecezji krakowskiej w 2002 roku, Archiwum Kurii Metropolitalnej w Krakowie, bez. sygn.

${ }_{44}$ Zob. Komisja Muzyczna Pielgrzymki, Bóg bogaty w mitosierdzie, pielgrzymka Jana Pawta II do Polski 2002, Kraków 2002. 
skiego SJ w opracowaniu Wojciecha Widłaka Bądź pozdrowiona święta Faustyno, a wszyscy zebrani - Gdzie mitość wzajemna i dobroć. Podczas komunii wierni rozpoczęli śpiew od pieśni Pan wieczernik przygotowat, następnie Chór Mariański wykonał utwór O Panie mój, wierni kontynuowali, śpiewając Ktaniam się Tobie i na zakończenie obrzędu schola sióstr zaśpiewała utwór Adorate, uwielbiam Cię. Jako dziękczynienie po komunii schola sióstr śpiewała pieśń Wspólnoty Błogosławieństw w opracowaniu Mieczysława Tulei Ten, który stowem. Całość liturgii została zakończona śpiewem wspólnym My chcemy Boga oraz Alleluja z II częściu oratorium Mesjasz Georga F. Haendla, którą wykonał Chór Mariański ${ }^{45}$.

18 sierpnia na krakowskich Błoniach ojciec święty odprawił uroczystą liturgię. $\mathrm{Z}$ tej okazji został przygotowany dla chóru zeszyt nutowy ${ }^{46}$. Śpiewano następujący repertuar Pod twa obronę z wiernymi, połączone chóry śpiewały Gaude Mater Polonia, a pieśn Kochajmy Pana - wszyscy wierni. Podczas obrzędu beatyfikacji schola wspólnie z wiernymi śpiewała inwokację Ciebie wielbimy i Tobie ufamy, a wszyscy wierni Jezu, ufam Tobie. Na przygotowanie darów ofiarnych chór śpiewał Czego chcesz od nas Panie w opracowaniu Józefa Świdra, wspólnie z wiernymi pieśń Jeden chleb napisaną przez o. Stanisława Ziemiańskiego. Na komunię świętą śpiewano z ludem pieśń Bądźże pozdrowiona, następnie sam chór śpiewał Ave verum Edwarda Elgara, wraz z wiernymi $U$ drzwi Twoich, a Pange lingua Antona Brucknera zaśpiewał sam chór. Na dziękczynienie wszyscy śpiewali wspólnie Ciebie Boga wystawiamy. Po zakończonej liturgii wierni śpiewali Boże coś Polskę, Barkę i Abba Ojcze. Chór wykonał Laudate Dominum Charles'a Gounoda ${ }^{47}$. Podczas uroczystej liturgii śpiewały połączone chóry z Krakowa i schola młodzieżowa. Dyrygentami byli Włodzimierz Siedlik i Wiesław Delimat, organistami: Wiesław Delimat, Witold Zalewski i Krzysztof Michałek. Kantorem podczas uroczystości był piszący te słowa.

19 sierpnia 2002 roku papież Jan Paweł II odwiedził kalwaryjskie sanktuarium, przybył tam z okazji 400-lecia jego istnienia. W bazylice oprawił ostatnią swoją mszę w Polsce. Podczas liturgii śpiewano z wiernymi tradycyjne pieśni kalwaryjskie. Na rozpoczęcie Gwiazdo śliczna, wspaniata, podczas składnia darów ofiarnych Jak dzieci do matki, na komunię Bądźże pozdrowiona, Pamiętaj, czto-

45 Zob. Komisja Muzyczna Pielgrzymki, Bóg bogaty w mitosierdzie, pielgrzymka Jana Pawta II do Polski 2002, dz. cyt., s. 9-41.

46 Zob. Komisja Muzyczna Pielgrzymki, Bóg bogaty w mitosierdzie, Eucharystia z Janem Pawtem II, Btonia Krakowskie 18 sierpnia 2002 roku, zeszyt nutowy, Kraków 2002.

47 Zob. Komisja Liturgiczna Komitetu Pielgrzymki, Bóg bogaty w mitosierdzie, Eucharystia z Janem Pawtem II, Btonia krakowskie 18 sierpnia 2002 roku, przewodnik pielgrzyma, Kraków 2002, s. 17-47. 
wiecze, na Jezusa, Upadnij na kolana, a na zakończenie śpiewano Królowej Anielskiej śpiewajmy, Weź w swa opiekę, Matko, przed Twoim obrazem, O, Kalwaryjska $\operatorname{Pani}^{48}$.

\section{Pielgrzymka papieża Benedykta XVI do archidiecezji krakowskiej}

Ojciec święty Benedykt XVI przybył do Krakowa w 2006 roku. 27 maja miało miejsce spotkanie z młodzieżą z całej Polski, zaś 28 maja odprawił uroczystą mszę na krakowskich Błoniach.

Specjalnie na ogólnopolskie spotkanie z młodymi została utworzona schola akademicka studentów Krakowa. Przygotowano śpiewnik chóralny ${ }^{49}$, w którym znalazły się następujące kompozycje: hymn Ogólnopolskiego Spotkania Młodych napisany przez Piotra Pałkę Nie lękajcie się, a także kompozycje tego samego muzyka: Kochamy Cię, ojcze święty, Pokój wam, O, piękności niestworzona, Mitość, Jesteśmy piękni Twoim pięknem, Panie, Easka Pana, Alleluja przed Ewangelia, Hymn na cześć Eucharystii, Jezu, ufam Tobie, Alleluja Gloria, Matko scynśliwych powrotów, Do Aniota stróża, Szukatem was, Po górach, dolinach. Śpiewano także kompozycje: Jesus Christ, you are my life Marka Frisiny, Wszystko Tobie Huberta Kowalskiego, Niechaj Cię, Panie Pawła Bębenka. Chórem i orkiestrą młodych dyrygował Piotr Pałka. Śpiew prowadził ks. Paweł Kummer. Wszyscy młodzi obecni na spotkaniu śpiewali, korzystając ze specjalnie dla nich przygotowanych śpiewników ${ }^{50}$.

28 maja 2006 roku, w dzień Wniebowstąpienia Pańskiego, ojciec święty odprawił na krakowskich Błoniach uroczystą liturgię Eucharystii. Zespół muzyczny tworzyły krakowskie chóry oraz studenci Akademii Muzycznej w Krakowie. Grała także Orkiestra Symfoniczna Akademii Muzycznej w Krakowie. Dyrygentami byli Stanisław Krawczyński i Wiesław Delimat, za organami zasiadali Witold Zalewski i Krzysztof Michałek. Śpiew z wiernymi prowadził piszący te słowa wraz z ks. Pawłem Kummerem. Dla chórów został przygotowany specjalny zeszyt nutowy ${ }^{51}$. Prawie całkowity repertuar tworzyły kompozycje i opracowania na chór i orkie-

${ }^{48}$ Zob. Jubileusz 400-lecia Sanktuarium Kalwaryjskiego 1602-2002. Teksty liturgiczne mszy świętej o Najświętszej Maryi Pannie Kalwaryjskiej, 19 sierpnia 2002 r.; II Pielgrzymka Ojca Świętego Jana Pawta II do Kalwarii Zebrzydowskiej, red. E. Lenart, Kalwaria 2002, s. 7-31.

${ }^{49}$ Zob. Komisja Muzyczna Pielgrzymki, Ogólnopolskie spotkanie mtodych z papieżem Benedyktem XVI. 27 maja 2006, Kraków2006.

${ }^{50}$ Zob. Śpiewnik. Ogólnopolskie spotkanie mtodych z Ojcem Świętym Benedyktem XVI. Btonia Krakowskie 27 maja 2006 roku, red. P. Iwanek, Kraków 2006.

${ }^{51}$ Zob. Komisja Muzyczna Pielgrzymki, Eucharystia pod przewodnictwem Ojca Świętego Benedykta XVI, Kraków Btonia, 28 maja 2006, Kraków 2006. 
strę Henryka Jana Botora. Począwszy od skomponowania dla papieża Benedykta XVI Tu es Petrusoraz śpiewów, które pod przewodnictwem kantora i chóru wraz z orkiestrą symfoniczną śpiewali wszyscy: Chrystus wodzem, Gloria, Święty, Święty, Baranku Boży, Zwycięzca śmierci, Otrzyjcie już tzy, ptaczący, Bądźże pozdrowiona, Ciebie, Boga, wystawiamy, Boże, coś Polskę. Ponadto chór wykonał także: Gaude Mater Polonia na rozpoczęcie liturgii, Alleluja przed i po Ewangelii ${ }^{52}$, Ave verum Wolfganga Amadeusza Mozarta, Tantum ergo Antona Brucknera na komunię. Po zakończonej mszy chór śpiewał Alleluja z oratorium Mesjasz Georga F. Haendla ${ }^{53}$.

Przypomnieć trzeba koniecznie jeszcze jedną liturgię.. Otóż papież odprawił mszę łacińską w kaplicy metropolity krakowskiego. Z założenia liturgia ta miała być cicha, tak się jednak nie stało. Podczas liturgii śpiewała schola gregoriańska Wyższego Seminarium Duchownego Archidiecezji Krakowskiej pod dyrekcją piszącego te słowa. Na specjalnie sprowadzonym na tę uroczystość pozytywie organowym ${ }^{54}$ grali Witold Zalewski i Wiesław Delimat ${ }^{55}$.

\section{Resume}

Reasumując, na samym początku trzeba tu jasno stwierdzić, że podczas wszystkich pielgrzymek papieży Jana Pawła II i Benedykta XVI w archidiecezji krakowskiej przygotowującym muzykę liturgiczną towarzyszyła zawsze świadomość - jak można było się przekonać z niniejszego artykułu - iż ma ona służyć pięknu liturgii i prowadzić serdeczną modlitwę ludu wiernego zebranego pod przewodnictwem papieża. Zgodne to było naturalnie z dokumentami Kościoła na temat muzyki kościelnej, które podkreślają, że „dzięki zjednoczeniu w śpiewie pogłębia się jedność serc, okazałość świętych obrzędów ułatwia wznoszenie myśli ku niebu, a całość odprawianych obrzędów jest obrazem i zapowiedzią tego, co dokonuje się w świętym mieście Jeruzalem” (MS 5). Nie bez znaczenia więc jest podkreślenie tego, jak bardzo troska ta była żywo obecna.

Powstawały nowe kompozycje. Niejednokrotnie wielkie i wspaniałe jak Beatus vir Henryka Mikołaja Góreckiego, Hymn uwielbienia Juliusza Łuciuka, Tu

52 Napisane przez Henryka Jana Botora z okazji ingresu do katedry wawelskiej przez kard. Stanisława Dziwisza w 2005 roku.

53 Zob. Komisja Liturgiczna i Muzyczna Archidiecezji Krakowskiej, Eucharystia z Ojcem Świętym Benedyktem XVI, Btonia krakowskie 28 maja 2006, Kraków 2006, s. 8-50.

54 Pozytyw organowy został skonstruowany przez firmę Kaczmarczyk z Zabrza. Instrument ma 4 głosy. Pozostał od tego czasu w kaplicy biskupa krakowskiego i służy do liturgii.

55 Słynne stało się powiedzenie Witolda Zalewskiego na antenie Radia Plus: „był jeden papież i dwóch organistów”. 
es Petrus Henryka Jana Botora. Na papieskie celebry tworzono mniejsze kompozycje, ale równie ważne takie jak na przykład inwokacje do błogosławionych i świętych, najczęściej komponowane przez Irenę Pffeifer i Mariana Machurę, a także pieśni do tekstów Marka Skwarnickiego. Nie brakło także nowej myśli muzycznej reprezentowanej przez Piotra Pałkę. Kompozycje nowe zawsze ubogacały i ozdabiały liturgie papieskie i co więcej, w ten sposób często wchodziły do kanonu śpiewów liturgicznych Kościoła. I znów, odwołując się do słów dokumentów Kościoła, można śmiało powiedzieć, iż zrealizowały się w tym wypadku owe zalecania:

niechaj przejęci duchem chrześcijańskim muzycy wiedzą, że są powołani do pielęgnowania muzyki sakralnej i powiększania jej skarbca. Niech tworzą melodie, które posiadałby cechy prawdziwej muzyki kościelnej i nadawałby się nie tylko dla większych zespołów śpiewaczych, lecz także dla mniejszych chórów i przyczyniałyby się do czynnego uczestnictwa całego zgromadzenia wiernych (KL 121).

Kolejnym ważnym wnioskiem z niniejszego opracowania jest szczególnie widoczna dbałość o właściwie miejsce dla śpiewu chóru i orkiestry. Nie bez znaczenia jest także fakt, iż do papieskich liturgii w Krakowie i archidiecezji zapraszane były zawsze zespoły wielkiej klasy i chóry na co dzień działające w kościołach parafialnych Krakowa i archidiecezji. Trzeba więc tutaj wszystkie te zespoły raz jeszcze przywołać. A były to: Chór i Orkiestra Filharmonii Krakowskiej, Chór Polskiego Radia w Krakowie, Capella Cracovienis z madrygalistami, Chór i Orkiestra Akademii Muzycznej w Krakowie, Chór Psalmodia Uniwersytetu Papieskiego Jana Pawła II w Krakowie, Chór Akademicki „Organum”, Chór Mariański z parafii NMP z Lourdes w Krakowie, Schola Cantorum Cracoviensis z kolegiaty św. Anny, chór katedralny i Chór Cecyliański, Chór Dominanta Uniwersytetu Ekonomicznego i wiele innych zespołów, których nazwy już wcześniej zostały w tym opracowaniu przywołane. Liturgie odbywały się z obecnością orkiestr dętych, symfonicznych, kameralnych i zespołów młodzieżowych. Wydaje się, że i tutaj należy przypomnieć dokument potwierdzający słuszność takiego kształtu muzycznych pielgrzymek. Prawodawca kościelny przypomina bowiem:

podczas liturgii mszy świętej zaleca się wykonywanie polifonii dawnej i nowszej w języku łacińskim i polskim, tak jednak, by nie wyłączać wiernych całkowicie z udziału w śpiewie. Muzykę wielogłosową, szczególnie dawnych mistrzów, Kościół zawsze uważał za nieoceniony skarbiec i dobro kultury (IEP 18). 
Istotny był także podczas papieskich liturgii $\mathrm{w}$ archidiecezji krakowskiej dźwięk organów, który zawsze miał na celu sprawić, by celebracja świętych obrzędów była piękna, dostojna i owocna zarazem. Organistami podczas tych uroczystych chwil życia Kościoła w Krakowie byli najwybitniejsi mistrzowie tego królewskiego instrumentu: Michał Woźny, Marian Machura, Mieczysław Tuleja, Witold Zalewski, Wiesław Delimat, Krzysztof Michałek, Henryk Jan Botor, Jan Rybarski, a także wielu innych. Nie mogło też być inaczej, skoro konstytucja o liturgii określa jednoznacznie, że „w Kościele łacińskim należy mieć w wielkim poszanowaniu organy piszczałkowe jako tradycyjny instrument muzyczny, którego brzmienie ceremoniom kościelnym dodaje majestatu, a umysły wiernych porywa do Boga i spraw niebieskich" (KL 120). I choć organy piszczałkowe wykorzystano podczas pielgrzymek tylko w kościołach oraz w kaplicy biskupa krakowskiego, to jednak wprawna ręka mistrza za każdym razem - także w polowych warunkach, w których odbywały się liturgie papieskie - muzyką organową oddawała chwałę Bogu i służyła modlitwie wiernych.

Jeszcze słowo warto dodać w związku z przywoływanymi śpiewami wiernych podczas papieskich celebracji. Wcześniej wszystkie te pieśni były drukowane w śpiewnikach dostępnych dla uczestników celebracji papieskich. Każda liturgia była tak przygotowana, by wierni nie czuli się jedynie słuchaczami. Pieśni i części stałe liturgii były dostosowane do formularza mszalnego. Wybierano jednocześnie pieśni najbardziej znane, by w ten sposób wierni czynnie i pełny sposób uczestniczyli w liturgii. Takie przygotowanie muzyki liturgicznej wynikało z soborowego myślenia, że „nie ma nic podnioślejszego i milszego w nabożeństwach liturgicznych nad zgromadzenie wiernych, które wspólnie w pieśni wyraża swoją wiarę i pobożność" (MS 16).

W całym więc zestawieniu muzyki liturgicznej podczas pielgrzymek papieskich w archidiecezji krakowskiej bardzo wyraźnie dostrzec można wielką troskę o jakość, piękno i modlitewny jej charakter. To być może dlatego papież Benedykt XVI po zakończonej liturgii na krakowskich Błoniach w 2006 roku miał powiedzieć „ta liturgia była piękna, bo piękna była muzyka podczas niej” ${ }^{56}$. Czyż mogą być większe słowa uznania dla tych, którzy przygotowywali jej kształt?

Jest więc pewne, że wszystkim, którzy prowadzili schole i chóry, ćwiczyli zespoły instrumentalne, orkiestry, grali na organach, prowadzili wspólny śpiew, komponowali i pisali nuty dla zespołów muzycznych papieskich pielgrzymek, należy się wielka wdzięczność. Od 1979 roku minęło wiele lat, niektórych ludzi, którzy tworzyli tę muzykę, już nie ma wśród żyjących, inni są na zasłużonej

\footnotetext{
${ }^{56}$ Słowa przekazane przewodniczącemu Muzycznej Komisji Pielgrzymki przez kard. Stanisława Dziwisza po zakończonej liturgii papieskiej.
} 
emeryturze, pozostali jeszcze dbają o sprawę muzyki archidiecezji krakowskiej. Im wszystkim należą się wielka wdzięczność i uznanie. To wspomnienie ma być takim właśnie przypomnieniem tych osób i ich wielkiej pracy. Bogu niech będą dzięki za wszystko i niech będzie On uwielbiony w tym, czego muzycy archidiecezji krakowskiej dokonali podczas papieskich pielgrzymek. I pewnie słuszne będzie przypomnienie na koniec, że „łługami nieużytecznymi jesteśmy, wykonaliśmy tylko to, co powinniśmy wykonać” (Łk 17, 10).

\section{Streszczenie}

Muzyka podczas papieskich pielgrzymek w archidiecezji krakowskiej (1979-2006)

Podczas wszystkich pielgrzymek papieży - Jana Pawła II i Benedykta XVI - w archidiecezji krakowskiej przygotowującym muzykę liturgiczną towarzyszyła zawsze świadomość - jak można było się przekonać z niniejszego artykułu - iż ma ona służyć pięknu liturgii i prowadzić serdeczną modlitwę ludu wiernego zebranego pod przewodnictwem papieża. Było to naturalnie zgodne z dokumentami Kościoła na temat muzyki kościelnej, które podkreślają, że „dzięki zjednoczeniu w śpiewie pogłębia się jedność serc, okazałość świętych obrzędów ułatwia wznoszenie myśli ku niebu, a całość odprawianych obrzędów jest obrazem i zapowiedzią tego, co dokonuje się w świętym mieście Jeruzalem” (MS 5). Nie bez znaczenia więc jest podkreślenie tego, jak bardzo troska ta była żywo obecna.

Powstawały nowe kompozycje. Niejednokrotnie wielkie i wspaniałe jak Beatus Vir Henryka Mikołaja Góreckiego, Hymn uwielbienia Juliusza Łuciuka, Tu es Petrus Henryka Jana Botora. Na papieskie celebry tworzono też kompozycje mniejsze, ale równie ważne, takie jak na przykład inwokacje do błogosławionych i świętych, najczęściej komponowane przez Irenę Pffeifer i Mariana Machurę, ale także pieśni do tekstów Marka Skwarnickiego. Nie brakło też nowej myśli muzycznej reprezentowanej przez Piotra Pałkę. Kompozycje nowe zawsze ubogacały i ozdabiały liturgie papieskie i - co więcej - w ten sposób często wchodziły do kanonu śpiewów liturgicznych Kościoła. I znów, odwołując się do słów dokumentów Kościoła, można śmiało powiedzieć, iż zrealizowały się w tym wypadku owe zalecania:

niechaj przejęci duchem chrześcijańskim muzycy wiedzą, że są powołani do pielęgnowania muzyki sakralnej i powiększania jej skarbca. Niech tworzą melodie, które posiadałby cechy prawdziwej muzyki kościelnej 
i nadawałby się nie tylko dla większych zespołów śpiewaczych, lecz także dla mniejszych chórów i przyczyniałyby się do czynnego uczestnictwa całego zgromadzenia wiernych (KL 121).

Kolejnym ważnym wnioskiem z niniejszego opracowania jest szczególnie widoczna dbałość o właściwie miejsce dla śpiewu chóru i orkiestry. Nie bez znaczenia jest fakt, iż do papieskich liturgii w Krakowie i archidiecezji zapraszane były zawsze zespoły wielkiej klasy i chóry na co dzień działające w kościołach parafialnych Krakowa i archidiecezji. Trzeba więc tutaj wszystkie te zespoły raz jeszcze przywołać. A były to: Chór i Orkiestra Filharmonii Krakowskiej, Chór Polskiego Radia w Krakowie, Capella Cracovienis z madrygalistami, Chór i Orkiestra Akademii Muzycznej w Krakowie, Chór Psalmodia Uniwersytetu Papieskiego Jana Pawła II w Krakowie, Chór Akademicki „Organum”, Chór Mariański z parafii NMP z Lourdes w Krakowie, Schola Cantorum Cracoviensis z kolegiaty św. Anny, chór katedralny i Chór Cecyliański, Chór Dominanta Uniwersytetu Ekonomicznego i wiele innych zespołów, których nazwy już wcześniej zostały w tym opracowaniu przywołane. Liturgie odbywały się z obecnością orkiestr dętych, symfonicznych, kameralnych i zespołów młodzieżowych. Wydaje się, że i tutaj należy przypomnieć dokument potwierdzający słuszność takiego kształtu muzycznych pielgrzymek. Prawodawca kościelny przypomina bowiem:

podczas liturgii mszy świętej zaleca się wykonywanie polifonii dawnej i nowszej w języku łacińskim i polskim, tak jednak, by nie wyłączać wiernych całkowicie z udziału w śpiewie. Muzykę wielogłosową, szczególnie dawnych mistrzów, Kościół zawsze uważał za nieoceniony skarbiec i dobro kultury (IEP 18).

Istotny był także podczas papieskich liturgii w archidiecezji krakowskiej dźwięk organów, który zawsze miał na celu sprawić, by celebracja świętych obrzędów była piękna, dostojna i owocna zarazem. Organistami podczas tych uroczystych chwil życia Kościoła w Krakowie byli najwybitniejsi mistrzowie tego królewskiego instrumentu: Michał Woźny, Marian Machura, Mieczysław Tuleja, Witold Zalewski, Wiesław Delimat, Krzysztof Michałek, Henryk Jan Botor, Jan Rybarski, a także wielu innych. Nie mogło też być inaczej skoro konstytucja o liturgii określa jednoznacznie, że „w Kościele łacińskim należy mieć w wielkim poszanowaniu organy piszczałkowe jako tradycyjny instrument muzyczny, którego brzmienie ceremoniom kościelnym dodaje majestatu, a umysły wiernych porywa do Boga i spraw niebieskich" (KL 120). I choć organy piszczałkowe wykorzystano podczas pielgrzymek tylko w kościołach oraz w kaplicy biskupa krakowskiego, to jednak wprawna ręka mistrza za każdym razem - także w polowych warunkach, w których odbywały się liturgie papieskie - muzyką organową oddawała chwałę Bogu i służyła modlitwie wiernych. 
Jeszcze słowo warto dodać w związku z przywoływanymi śpiewami wiernych podczas papieskich celebracji. Wcześniej wszystkie te pieśni były drukowane w śpiewnikach dostępnych dla uczestników celebracji papieskich. Każda liturgia była tak przygotowana, by wierni nie czuli się jedynie słuchaczami. Pieśni i części stałe liturgii były dostosowane do formularza mszalnego. Wybierano jednocześnie pieśni najbardziej znane, by w ten sposób wierni czynnie i pełny sposób uczestniczyli w liturgii. Takie przygotowanie muzyki liturgicznej wynikało z soborowego myślenia, że „nie ma nic podnioślejszego i milszego w nabożeństwach liturgicznych nad zgromadzenie wiernych, które wspólnie w pieśni wyraża swoją wiarę i pobożność" (MS 16).

W całym więc przedstawieniu muzyki liturgicznej podczas pielgrzymek papieskich w archidiecezji krakowskiej bardzo wyraźnie dostrzec można wielką troskę o jakość, piękno i modlitewny jej charakter. To być może dlatego papież Benedykt XVI po zakończonej liturgii na krakowskich Błoniach w 2006 roku miał powiedzieć „ta liturgia była piękna, bo piękna była muzyka podczas niej" ${ }^{37}$. Czyż mogą być większe słowa uznania dla tych, którzy przygotowywali jej kształt?

Jest więc pewne, że wszystkim, którzy prowadzili schole i chóry, ćwiczyli zespoły instrumentalne, orkiestry, grali na organach, prowadzili wspólny śpiew, komponowali i pisali nuty dla zespołów muzycznych papieskich pielgrzymek, należy się wielka wdzięczność. Od 1979 roku minęło wiele lat, niektórych ludzi, którzy tworzyli muzykę, już nie ma wśród żyjących, inni są na zasłużonej emeryturze, pozostali jeszcze dbają o sprawę muzyki archidiecezji krakowskiej. Im wszystkim należą się wielka wdzięczność i uznanie. To wspomnienie ma być takim właśnie przypomnieniem tych osób i ich wielkiej pracy. Bogu niech będą dzięki za wszystko i niech będzie On uwielbiony w tym, czego muzycy archidiecezji krakowskiej dokonali podczas papieskich pielgrzymek. I pewnie słuszne będzie przypomnienie na koniec, że „sługami nieużytecznymi jesteśmy, wykonaliśmy tylko to, co powinniśmy wykonać” (Łk 17, 10).

\section{Summary}

\section{Music during Papal Pilgrimages to the Cracow Archdiocese}

During all papal pilgrimages - of John Paul II and of Benedict XVI to the Cracow Archdiocese - people responsible for liturgical music of these events were invariably aware - as it is proved in this paper - that the role of music was to serve liturgy, to lead the prayers of God's people congregated before the Pope. Therefore, they seemed to fulfill all the Church prescripts on sacred music specifying that "by the union of voices, minds

\footnotetext{
${ }^{57}$ Słowa przekazane przewodniczącemu Muzycznej Komisji Pielgrzymki przez kard. Stanisława Dziwisza po zakończonej liturgii papieskiej.
} 
are more easily raised to heavenly things by the beauty of the sacred rites, and the whole celebration more clearly prefigures that heavenly liturgy which is enacted in the holy city of Jerusalem." (MS 5) It is then significant to emphasise a great concern given to liturgical music during the mentioned events.

Papal pilgrimages were an inspiration to create new compositions, some of them of immense and considerable value, e.g.: Beatus Vir by Henryk Mikołaj Górecki, Hymn uwielbienia [Hymn of Adoration] by Juliusz Euciuk or Tu es Petrus by Henryk Jan Botor. Amongst the other - lesser, yet not less important compositions, were invocations to the Blessed and the Saints, composed mostly by Irena Pffeifer and Marian Machura, or the chants composed to the texts of Marek Skwarnicki. There were also new thoughts and ideas, e.g. of Piotr Pałka. The new compositions invariably enriched and ornamented papal liturgies, being even introduced into the canon of liturgical chants of the Church. It should be mentioned here that these compositions also complied with the prescriptions of the Church in this matter:

Composers, filled with the Christian spirit, should feel that their vocation is to cultivate sacred music and increase its store of treasures.Let them produce compositions which have the qualities proper to genuine sacred music, not confining themselves to works which can be sung only by large choirs, but providing also for the needs of small choirs and for the active participation of the entire assembly of the faithful (SC 121).

Another conclusion which might be drawn from this paper is the utmost care with which choirs and orchestras were selected for the events. It should be noted that the choirs and orchestras invited to papal liturgies in Cracow and in the Cracow Archdiocese were always of highest standard, the choirs daily active in the parish churches of Cracow and the Archdiocese. Amongst them are: The Choir and Orchestra of the Cracow Philharmonic, The Choir of the Polish Radio of Cracow, Psalmodia The Choir of the Pontifical John Paul II University in Cracow, The "Organum" Academic Choir, The Mariański Choir from Our Lady of Lourdes Lourdes Parish Church in Cracow, Schola Cantorum Cracoviensis from Collegiate Church of St. Ann, The Cathedral Choir and the Cecilian Choir, Dominanta Choir from the Cracow University of Economics, as well as many other music groups, also those already mentioned. The liturgies were accompanied by brass, symphonic and chamber orchestras, as well as by youth bands. Also here it seems appropriate to quote the relevant document with the fully complied precept:

during the liturgy of the Holy Mass it is prescribed to perform the old and the new polyphonic music in Latin and in the Polish language, however, in such a manner so as not to exclude the faithful from participation in 
singing. The polyphonic music, especially this composed by the old masters, is regarded by the Church as inestimable treasure and cultural heritage (IEP 18).

In the music setting for papal pilgrimages an equally vital element was the sound of pipe organ whose role was to make the celebrations of the holy rites more beautiful, grand and also fruitful. The organ players of the events in question were the most renowned Cracow organists: Michał Woźny, Marian Machura, Mieczysław Tuleja, Witold Zalewski, Wiesław Delimat, Krzysztof Michałek, Henryk Jan Botor, Jan Rybarski and many others. It could not be otherwise as the Vatican Constitution on Liturgy clearly specifies that:

In the Latin Church the pipe organ is to be held in high esteem, for it is the traditional musical instrument which adds a wonderful splendor to the Church's ceremonies and powerfully lifts up man's mind to God and to higher things (SC 120).

And although the pipe organs were only played in churches and at the Cracow Bishop Chapel, the masters of the organ also in the so called field conditions of papal pilgrimages used their master skills to glorify God and serve to the congregated faithful.

Finally, the chants sung by the congregated people should be brought upon. These chants were first collected in song books available for pilgrimages. Each liturgy was arranged in such a way so that the faithful could participate, not remain mere listeners. The chants were adjusted to the order of the Mass Service, carefully selected from those well known to enable the congregated people to participate most actively in prayers. It was entailed by the post Vatican II way of thinking:

One cannot find anything more religious and more joyful in sacred celebrations than a whole congregation expressing its faith and devotion in song. Therefore the active participation of the whole people, which is shown in singing, is to be carefully promoted as follows (MS 16).

In the whole presentation of liturgical music during papal pilgrimages to the Cracow Archdiocese, a very important thing is to focus on a great care for quality, beauty and the prayer-like character of it. Perhaps it was noticed indeed by Pope Benedict XVI himself, when upon finishing the Mass Service on the Cracow Błonia Fields in 2006, he commented that "liturgy was beautiful and liturgical music as well." Could there be any better words of esteem for those who had arranged it?

It goes without saying that all people who prepared scholas, choirs, supervised and trained instrumental bands, orchestras, who played the organ, who conducted common 
singing, composed and wrote music notes during all papal pilgrimages deserve highest praise and particular gratefulness. Many years have passed since 1979, some of those people are no longer living, some are long retired, the others are still active in the matters of Church music of the Cracow Archdiocese. They all deserve recognition. This monograph is to commemorate all those people and their immense work. We thank God for them; may He be praised in all their music created for the benefit of papal pilgrimages in the Cracow Archdiocese. Let us finish with probably the most relevant citation from St. Luke: "We are unworthy servants; we have only done what was our duty." (Luke 17:10).

Stowa kluczowe muzyka kościelna, papież Jan Paweł II, papież Benedykt XVI, orkiestra, chór, kopozycje, dyrygenci

Key terms Church music, Pope John Paul II, Pope Benedict XVI, orchestra, choir, composers, conductors.

\section{Bibliografia}

Bóg bogaty $w$ mitosierdzie, Eucharystia z Janem Pawtem II, Btonia Krakowskie 18 sierpnia 2002 roku, zeszyt nutowy, Kraków 2002.

Biziak L., Irena Pfeiffer muzyk i pedagog, praca licencjacka napisana pod kierunkiem ks. dr. Roberta Tyrały, Papieska Akademia Teologiczna w Krakowie, Kraków 2002.

Biziak L., Miejsce Ireny Pfeiffer $w$ historii muzyki kościelnej i jej wktad w świetle soborowej odnowy muzyki liturgicznej, praca magisterska napisana pod kierunkiem ks. dr Roberta Tyrały, Papieska Akademia Teologiczna w Krakowie, Kraków 2004.

Komisja Liturgiczna Komitetu Pielgrzymki, Bóg bogaty $w$ mitosierdzie, Eucharystia z Janem Pawtem II, Btonia krakowskie 18 sierpnia 2002 roku, przewodnik pielgrzyma, Kraków 2002.

Komisja Liturgiczna Komitetu Pielgrzymki, Bóg bogaty w mitosierdzie, pielgrzymka Jana Pawta II do Polski 2002, Kraków 2002.

Dekret Metropolity Krakowskiego, nr 727/2002

Dziękczynienie za pielgrzymkę Ojca Świętego do Ojczyzny, Eucharystia z Janem Pawtem II przy ottarzu Ojczyzny, katedra wawelska 17 czerwca 1999, godz. 7. 30, red. S. Koperek, Kraków 1999.

Komisja Liturgiczna i Muzyczna Archidiecezji Krakowskiej, Eucharystia z Ojcem Świętym Benedyktem XVI, Btonia krakowskie 28 maja 2006 roku, Kraków 2006.

I pielgrzymka Jana Pawta II do Krakowa, Archiwum Kurii Metropolitalnej w Krakowie, bez. sygn.

II Pielgrzymka Jana Pawta II do Krakowa w 1983 roku, Archiwum Kurii Metropolitalnej w Krakowie, bez. sygn. 
II Pielgrzymka Ojca Świętego Jana Pawta II do Kalwarii Zebrzydowskiej, red. E. Lenart, Kalwaria 2002.

III Pielgrzymka Jana Pawta II do Krakowa w 1983 roku, Archiwum Kurii Metropolitalnej w Krakowie, bez. sygn.

Jubileusz 400-lecia Sanktuarium Kalwaryjskiego 1602-2002, teksty liturgiczne mszy świętej o Najświętszej Maryi Pannie Kalwaryjskiej, 19 sierpnia 2002 r.

Kanonizacja Btogostawionej Jadwigi Królowej, Btonia Krakowskie 8 czerwca 1997 roku, red. Komisja Muzyczna Pielgrzymki, Kraków 1997.

Modlitewnik pielgrzyma, z Janem Pawtem II w archidiecezji krakowskiej 4-10 czerwca 1997, red. S. Koperek, Kraków 1997.

Msza święta Jana Pawta II z podniesieniem relikwii błogostawionej Jadwigi Królowej, katedra na Wawelu 10 czerwca 1987 roku, Kraków 1987.

Komisja Muzyczna Pielgrzymki, Msza święta pontyfikalna o Najświętszym Sercu Pana Jezusa sprawowana przez Ojca Świętego Jana Pawta II, w czasie której dokona beatyfikacji siostry Bernardyny Jabtonskiej i siostry Marii Kartowskiej, Zakopane 6 czerwca 1997 roku, Kraków 1997

Komisja Muzyczna Pielgrzymki, Msza święta sprawowana przez Ojca Świętego Jana Pawta II w Milenium Diecezji Krakowskiej, Błonia Krakowskie 15 czerwca 1999 roku, Kraków 1999. Na jubileusz św. Stanistawa, zeszyt chóralny, Kraków 1979.

Na spotkanie z Janem Pawtem II, Btonia Krakowskie 10 czerwca 1987, zeszyt nutowy, Kraków 1987.

Komisja Muzyczna Pielgrzymki, Ogólnopolskie spotkanie mtodych z papieżem Benedyktem XVI. 27 maja 2006, Kraków2006.

Pielgrzymka Jana Pawta II do Krakowa w 1991 roku, Archiwum Kurii Metropolitalnej w Krakowie, bez. sygn.

Pielgrzymka Jana Pawta II do Krakowa w 2002 roku, Archiwum Kurii Metropolitalnej w Krakowie, bez. sygn.

Pielgrzymka Jana Pawta II w Krakowie w 1999 roku, Archiwum Kurii Metropolitalnej w Krakowie, bez. sygn.

Protokót z posiedzenia komisji muzycznej pielgrzymki papieża w 1983 w Krakowie, II Pielgrzymka Jana Pawta II do Krakowa w 1983 roku, Archiwum Kurii Metropolitalnej w Krakowie, bez. sygn.

Tyrała R., Jan Pawet II $w$ muzyce polskiej, praca magisterska napisana pod kierunkiem prof. Adama Walacińskiego, Akademia Muzyczna w Krakowie, Kraków 1997.

Tyrała R., Tyrała, Kulturowy i religijny kontekst twórczości kompozytorskiej Henryka Mikotaja Góreckiego (+2010). "Niebiańskie polany” jako przestanie jego kompozytorskiej twórczości, „Pro Musica Sacra”, t. 9, Kraków 2011, s. 11-17.

R. Tyrała, Polska muzyka sakralna inspirowana osoba i dziatalnościa Jana Pawta II, „Polonia Sacra” VIII (XXVI) nr 15/59 (2004), s. 353-376. 
Sktad komisji muzycznej pielgrzymki papieża Jana Pawta II do archidiecezji krakowskiej w 1997 roku, Archiwum Archidiecezjalnej Komisji Muzyki Kościelnej, bez. sygn.

Sktad komisji muzycznej pielgrzymki papieza Jana Pawta II do archidiecezji krakowskiej w 1999 roku, Archiwum Kurii Metropolitalnej w Krakowie, bez. sygn.

Sktad komisji muzycznej pielgrzymki papieża Jana Pawta II do archidiecezji krakowskiej w 2002 roku, Archiwum Kurii Metropolitalnej w Krakowie, bez. sygn.

Śpiewnik Ogólnopolskie spotkanie mtodych z Ojcem Świętym Benedyktem XVI, Btonia Krakowskie 27 maja 2006 roku, red. P. Iwanek, Kraków 2006.

Tysiac lat diecezji krakowskiej, Eucharystia z Janem Pawtem II, Btonia Krakowskiej 15 czerwca 1999, red. S. Koperek, Kraków 1999.

Wspomnienia o pielgrzymkach papieskich doc. Mariana Machury z dnia 19 maja 2014 roku, Archiwum Archidiecezjalnej Komisji Muzyki Kościelnej, bez. sygn.

Wspomnienie ks. prof. Jacka Żurka, Archiwum Archidiecezjalnej Komisji Muzyki Kościelnej, bez. sygn. 